\title{
The Role Of National Land Agency In Acceleration Of Land Registration For Legal Certainty
}

\author{
"Muhammad Yamin', Zaidar², Zakiah"
}

\begin{abstract}
ARTICLE HISTORY

$\begin{array}{ll}\text { Received } & : 24 \text { April 2018; } \\ \text { Reviewed } & : 28 \text { April 2018; } \\ \text { Accepted } & : 30 \text { April 2018; } \\ \text { Published } & : 30 \text { April 2018. } \\ \text { KEYWORDS }\end{array}$

Land Registration; Legal Certainty The Role;

National Land Agency (NLA).

\section{CORRESPONDENSE}

${ }^{1}$ Department of State Administrative Law, Program Specificity of Agrarian Law, Faculty of Law University of Sumatra Utara, Medan, Indonesia. Email:yaminlubis16@gmail.com

2 Department of State Administrative Law, Program Specificity of Agrarian Law, Faculty of Law University of Sumatra Utara, Medan, Indonesia. Amail: zaidarperwira@gmail.com

3 Department of State Administrative Law, Program Specificity of Agrarian Law, Faculty of Law University of Sumatra Utara, Medan, Indonesia.
\end{abstract}

\begin{abstract}
A B S T R A C T
Rapid growing of population in one hand and economic development on the other hand has caused the increasing of demand for land in Indonensia. In the mean time, there are laso lot of land despute that results in tension and conflict in the society. This condition will surely cause problems in controlling and ownership of the land. This research aims to identify the factors which cause the conflict (dispute) of land, by doing inventory to the lands which is owned by the community (whether it is registered or not registered). From this temporary research result, it is found that, the implementation of the land registration in Deli Serdang district (the research location) has not happened as expected. It can be seen from the number of land which has not been registered. This condition will certainly trigger land conflicts or disputes in society, relates to ownership boundary disputes, control of illegal land (arable land), inheritance disputes, etc. Certificate of ownership mostly exist in urban area. The lack of interest by the community to join the land registration is due to various reasons. They are: 1) the community do not recognize the purpose of land registration, 2) the cost of registation is relatively expensive, 3) the management is convoluted, 5) arable land. In this research, the role of National Land Agency (NLA) as the organizer of land registration is not optimal. It is visible that the NLA is just passive and just waiting for the owner come to register their lands. Therefore, NLA should be more involved in land registration by conductingand and counseling for the community. It is hoping that the community will be motivated to register their lands for achieving the legal certainty.
\end{abstract}

\section{Introduction}

Land conflict is absolutely an essential issue for human life. Land has an extremely important role, between human and the land has an eternal relation that is unable to be separated from each other. The increasing number of citizens will indirectly cause the demand of land increasing. Besides the demand for development, there is also for public interest, while the number of available land is limited (by the meaning of not increasing). There is not impossible if the price of the land is increasing over the time. The imbalance between the land supply and the demand of land automatically will cause problems. 
Along with the times, it is not rare that on the land which is owned or controlled will cause dispute, both among the heir or with other parties even with the government. Most disputes arise in result of unclear status of land ownership, illegally land ownershipetc In fact, there are still many people who do not understand the function of land registration, and according to them land will be meaningful if the land that they owned has its letter (any letter it is and whoever published it) as long as the making of the letteris related to the government agencies, which means their landhas been registered, (for example: an evidence letter of Land and Building Tax or other letter, such as privately made letter of sale and purchase, sale and purchase which is known / approved by the head of village / headman / sub-district head etc.). This mistaken understanding should not be allowed to keep growing and should be aligned to the actual sense of understanding in accordance with the law.

By observing the land conflict in Indonesia which is continuously increasing, the root of the problem is in the absence of legal certainty in the land tenure.

Based on existing data in Province Government of North Sumatera, in 2014 has been recorded 714 cases, which include land conflicts between community and PTPN, community and foreign plantation companies, and the community with the community. Province Government of North Sumatera, District Government, and City Government should open up with the BPN in effort to resolve land conflicts in North Sumatera, in order to realize the Article 33 paragraph (3) of the 1945 Constitution which states "the earth, water and natural resources that contained therein is controlled by the state and used for the maximum prosperity of the community. (Speech by Deputy Governor of Sumatera Utara in delivering of certficates of land in strategic programs National Land Agency (NLA - RI, March 13 2014). Legal certainty is the main purpose of organizing the land registration and is a thing that absolutely should be there in order to maintain the stability of the construction and to realize the legal certainty of land ownership.
The legal certainty that points outin the land registration will bring a result by giving a document as an evidence of land right which is called as certificate by NLA whom is the national administering agency for the beneficiary, which this certificate serves as an authoritative evidentiary for the rights over the land.

By having legal protection and legal certainty to the right holders, it means that every citizens can directlycontroltheir lands safely. Therefore, if every piece of the lands have been registered and have been functioned by the right holders, basicallythere has been alegal guarantee of the rights of every piece of the landswhich have been registered legally, and its positive impact can reduce the land problems, especially that regarding to the usage and the utilization evenmaintain the rights including the property that has attached to it.

Responding to the various issues above in order to achieve the legal certainty over the land and the good administration of land, it is presumed that the government programs in the effort to accelerate the certification of the land needs to be re-examined. For this case the active role from $\mathrm{BPN}$ is extremely expected so that the prosperity of community which all this time has been always left behind can be achieved. NLA and his staff shave to be fair and aligned to the right parties in resolving the land conflicts in each of the regions.

\section{Disputes or Conflicts of Land and Land Registration}

Term of dispute according to Indonesia Dictionary is interpreted as a conflict or argument, whereas in the English vocabulary this term is defined into two (2) terms, that are conflict and dispute, which both of them imply the existence of differences in interests between the two parties or more, but they is distinguishable. According to Coser, conflicts involve struggles betwen two or more people over values, or competition for status, power, or scarce resources. It was told by Coserw hich is written by Moore in his book The Function of Social Cnflic, that if the conflict has been apparent 
(manifest) then, it is called dispute. ${ }^{1}$ Meanwhile, according to Rahmadi Usman, conflict as a conflict between the parties to resolve the problem that if the conflict is not resolved properly, can interfere the relationship between the concerned parties. In that case it can be stated that as long as all the parties can resolve the conflict properly then there will not be dispute, but if thing happens otherwise, the parties are unable to reach an agreement for a solution of solving the problem so there will arise dispute. ${ }^{2}$ Thus in every conflictsin community will always contains potential of dispute.

Land conflict or land dispute consists of 2 (two) syllables, those are land and dispute. Land dispute, in the language of conflict is categorized as manifest conflict and emerging conflict. ${ }^{3}$

Dispute or conflict is unable to be avoided in thecommunitythat are developing, will not be able to prevent the consequences of the various activities which will collide against each other.In this collision will not be able to be dodged about the arising conflict which eventually will be transformed as a dispute or lack of understanding that can occur all the time. This opposition condition seems as insignificant at first glance that might be ignored, but it can suddenly appear without being estimated previously. 4

Describing the meaning of a dispute which is described above shows that a dispute will occur when there are two conflicting interests that can not be united, but not all the disputes must be resolved through the court. 5 This is different with the formulation of dispute which is embraced by the National Land Agency, which is according to Article 1 paragraph (1) of the Regulation of the Minister of Agrarian / Head of

\footnotetext{
1 Moore, Cristopher W. 1999, The Mediation Process Practical Strategis for Resolving Conflict, Jossey-Bass Publishers, San Francisco, p.

2 Siti Megadianti Adam and, Takdir Rahmadi, 2003, Pilihan Penyelesaian Sengketa Di luar Pengadilan, Citra Aditya Bandung, , p. 1

3 Maria Sumardjono, 2008 Mediation Land Conflict, Jakarta, , page, $2-3$

4 Priyatna Abdurrasyid, 2008, Beberapa Bentuk Hukum Sebagai Pengantar Menuju Indonesia Emas 2020, PT Fikahati Aneska, Jakarta, p.
}

National Land Agency Number 1 Year 1999 about Procedures for Handling Land Dispute is a different opinion regarding:

1. The validity of a right;

2. Granting the land rights;

3. Registration of land rights including transition and publishing the document as a evidence of its right between the concerned parties as well as between the concerned parties with the BPN agency.

Furthermore, in the decision of the Head of National Land Agency Republic of Indonesia Number 34 Year 2007 on Technical Guideline for Management and Settlement In Land Issuewas held a distinction between dispute and conflict. Disputeisa value difference, opinion interest or perceptions between individuals or legal entities (private or public) about the status of tenure or ownership status or the status of usage or utilization of a certain parcel of land by a particular party, or the status of an administrative decision regarding controlling, ownership, and usage or utilization on a certain parcel of land.

As a form of executing the state authority as a Ruler Agency and in order to provide legal protection of land right, so NLA organizes aland registrationthat the purpose is to guaranteethe legal certainty of the owned-by-individual land, legal entities or state lands. 6

In order to resolve the arising land conflict and create a legal certainty over the land ownership, it is necessary to start a research, by conducting an inventory to the land initially, whether it is registered or not registered, especially at Deli

\footnotetext{
5 Kurniati Nia, 2016, Agrarian Law Dispute Resolution through Arbitration In Theory And Practice, Refika Aditama,, p. 160

6 Hutagalung Arie Sukanti, 2013, The Underlying Conception of Completion of the National Land Law, An Inauguration Speech of Permanent Professor in Agrarian Law, Faculty of Law UI,
} 
Serdang regency which is used as the research location.

\section{Problem Identification}

This research attempts to find out the solution in order to resolve the problem of legal certainty to land ownershipas an effort to minimize the land conflict by associated with the role of NLA as an Institute of Land Registration Organizer.

1. Does the cause of land conflict happen because there are still lots of unregistered lands?

2. How is the implementation of land registration in the District of Deli Serdang?

3. How is the role of Land Office in the effort to realize the acceleration of land certification in order to conduct the good administration of land in Indonesia?

\section{Result And Discusion}

Deli Serdang District is one of the areas from the 33 districts / cities in North Sumatra province, with Lubuk Pakam as its capital city. In 2004 this district was re-experiencing a change, both in geography and administration, after the regional expansionby the birth of Serdang Bedagai, according to Constitution Number 36 in 2003 , so the variety of owned potential region will alsohave an effect. Due to the regional expansion, the total area now becomes 2349.62 $\mathrm{km} 2$ comprises of 22 districts and 403 villages / kelurahan, which is stretching to reach $3.34 \%$ of the area of North Sumatra.

Deli Serdang 2 * 57 "North Latitude, 3 * 16" South latitude, 98 * 33 "East, is occupying an area of $2.497 .72 \mathrm{~km} 2$, which consists of 22 districts and 394 Villages / Kelurahan. The north of Deli Serdang is bordering with Langkat District and the Strait of Malacca, in the South borders with Karo and Simalungun, in the West borders Langkat District and Karo and in the East borders with Serdang Bedagai.

The whole total area of Deli Serdang is (2.497.72 $\mathrm{Km}$ ), with the number of land parcels which have been registered about 217.123, with the details: 1). Property Right (177 586) parcels of land, 2). HGB (38 713) parcels of land, and the Right to Use (824) plot. While 7 of the district that become the research location, from 578 respondents who answered only about 153 (26.47\%) plots were registered. By observing this reality, there is a tendency for registering all of the lands in Deli Serdang, it is predicted to take up to 200 years.

To find out what are the rights which are base of the responden, it can be seen in the table 1 below

Tbel 1 Proof of Ownership

\begin{tabular}{|l|l|l|}
\hline Criteria & Frequency & Percentage (\%) \\
\hline Certificate & 153 & 26.47 \\
\hline SK Head & 267 & 46.19 \\
\hline Letter of Purchase & 88 & 15.22 \\
\hline None at all & 70 & 12.11 \\
\hline Amount & 578 & 99.99 \\
\hline
\end{tabular}

The abovetable shows that only 153 of the 578 respondents $(26.47 \%)$ that have a certificate. The rest only have evidence in the form of SK Head by amount of 267 respondents (46.19), 88 $(15: 22 \%)$ sale and purchase letter. While 70 respondents have no evidence of ownership at all. They just control the land by inhabiting it physically while there is no juridical evidence. The condition above shows that there are still a lot of land that do not have the land status of legal certainty. Therefore it is not surprising that the land issue which is because of the land right 
will be more and more. If this condition is allowed to drag on, then the fear of conflict/land conflict will be more widespread in this region.

Inadequate number of certificate that exists in the community which is being studied will influence to the pattern of land ownership, which is eventually willarisea dispute/conflict.
The correlation between knowledge/ understanding of the meaning of the land registration is unable to be separated from the number of certificates that have been issued by the Land Office.

The level of public knowledge of the Land Registration can be seen in the table 2 below

Table 2. Public understanding About Land Registration

\begin{tabular}{|c|c|c|}
\hline Criteria & Frequency & Percentage (\%) \\
\hline Understand & 255 & 44.11 \\
\hline Do not understand & 323 & 55.88 \\
\hline Amount & 578 & 99.99 \\
\hline
\end{tabular}

The meaning of the table figure of 578 respondents showed that most of the community do not understand the meaning of the land registration is $323(55.88 \%)$. The rest 255 $(44.11 \%)$ claimed to understand, but only a part of them had registered their lands.

Those who do not understand said that the certificateis just a letter of land. Therefore it is natural that the number of certificate is not too much in the research area. They who are being studiedare more convinced that even their landsdo not certified, there is no any existing problem for them. The land owner still safely recognized it from other disruptions even if they do not have proof of their land rights. So in fact more communitydoes not understand the meaning of a land certificate or does not understand about the land registration.

This condition will be difficult to be achieved if the development that is implemented was unfavorable to small community. Medium community would not have thought of registration of their land. They presumed that land register will entail excessive cost, while they do not understand what is the benefit (profit) that result from the land registration (certificate).

This opinion is due to their ignorance, or their understanding of law is really limited. There are some people assume that what is the purpose of land register, and according to them land is meaningful if the land has its letters, (regardless of its form, and whoever published it) as long as the action is relatedto government agency (village head), which meanstheir lands already have a legal force, For example: proof of tax payment, a letter issued by the village chief, letter of sale and purchase, etc.). This sort of thing according to some people is already regarded as an indication that the land is being registered. Therefore, based on the reasons which is given by the respondents can be recognized what factors that cause the low interest of society to register their lands:

a. Community factor; in this case the level of legal awareness and public knowledge about the benefit and importance of land registration is still low

b. The expensive registration fee

c. The implementation takes a long time

d. Lack of socialization or legal counseling for the community, which resulted in the community does not understand at all the meaning of the land registration;

e. The bureaucracy factor;

f. The facility factor.

The Role of Land Office in the Acceleration of Land Certification in order to Achieve Good Administration 
A role is an assessment of how far is the function of a person or entity in supporting the achievement of the desired purpose, in this case the Land Office, and thus expected for aexpected achievement which is good land administration.

The land office is the executor of land registration (National Land Agency), which has a strategic role in providing services directly for the public, especially regarding land registration in order to ensure legal certainty for the holder of land right. Registration of land right is an essential thing in the administration to safeguard a person's rightsof land for the realization of land stewardship and accurate as well as secured land administration, which is the country's obligation to carry out the task of land registration.

Deli Serdang Land Officein order to reach these goals has been taking steps to empower all the existing capabilities, because land registration is a manifestation of legal certainty. Then it is a big task for the Land Office in the future, by observing the increasing usage and utilization of land in the future, while the number of available land is limited. This condition if not immediately beingresponded, so it is worried that land conflict is not getting higher. In this case, Deli Serdang Land Office continues its effort to encourage and increase the legal awareness of public by improving the services to the public or through legal counseling or dissemination to the public on a regular basis (periodically), hopefully the public will be motivated to register their lands in order to create legal certainty of land rights. By holding the good land administration clearly will benefit for all parties. The advantages include:

1. It will provide security guarantee for the use of its owner;

2. To encourage or increase taxes by the country;

3. It can boost the function of land as collateral (mortgage bank);

4. Increase the land market surveillance;

5. It can protect the state land;

6. It can reduce land conflicts; can facilitate landreform activities, both in villages and urban planning activities and also improve infrastructure;

7. Encourage the environmental management becomes better; and can provide a good land statistical data.

The result of the interview with $\mathrm{Mr}$. Indra Imanuddin, $\mathrm{SH}$, Land Rights and Land Registration Office of Deli Serdang, in order to accelerate the certification of the land of Land Office has made the programs such as:

1. To provide a maximum service in the service area, through five (5) priority program of work, namely:

a. Build a public confidence in Land Office of Deli Serdang District

b. Improve the services and the implementation of land registration;

c. Dispute resolution and conflict over land

d. Organizing the land management system;

e. Reforming the institutional / infrastructure improvements.

2. Provide counseling about land. Here Land Office plays a major role in effort to improve land registration by performing routine (intensive) counseling to raise public legal awareness.

By the reality on the ground, legal counseling is still incidental. Indeed, there are some activities which is held by the Land Office with the head of the village as in the bulk certification program (Prona) is more incidental. Besides the government's bulk certification, there is also another program, such as the Adjudication Program, LARASITA Program (People's Service Land Certification). , is one of National Land Agency (NLA) effort to improve the acceleration of the land certification, by using pick up the ball system, where people do not need to come to the Land Office. NLA just needs to appoint a location, for example the village office and then people come to the specified location by bringing the files which is related to the requested right, furthermore NLA will process the application. It is unfortunate that this 
program is not going well, the main problem also depends on the cost. Although the communities are provided with easiness to register the land, both process and procedure, but if the cost stays the same as with the Land Office, then creating a new program will be useless, because the one which is desired by the community is low cost, and quick process.

\section{CONCLUSION}

The cause of the land conflict in Deli Serdang District is because there are still many unregistered lands. In fact, in several other research locations, there is land which is held by the public, is land which is owned by the plantation company, but their community recognition has controlled the land since a long time. This conditions has caused trouble and rise conflict in community. Society believes that even if there is no certificate, the land has been cultivated land. People forget that the protection of land rights will not appear if the land is not registered.

That the registered lands in the research location (Deli Serdang district), just includes private land which is mostly located in urban areas. While in the countryside land registration is still lower if it is compared to the landin rural area. Most of the registered lands are the lands which are earmarked for plantation activities under Cultivation Rights and the owner is big companies with professional investment in the field of large estates. There are many public perceptions that the process of land registration in Indonesia is still so complicated, and the cost is expensive. In fact, if the people comply with the existing rules, then the process will be easy and run smoothly. Therefore, if public owns an unregistered land (certified), the registration is immediately done in the Land Office so that the land we have, is valid before the law.

The role of land office in an effort to realize the acceleration of the land certification in order to be a good land administration is still a desire and has not been achieved as it should be. In doing its role, Land Office should provide maximum service through five, and (5), program of work priorities. They are; a. Build a public confidence in Land Office of Deli Serdang District

b. Improve the services and the implementation of land registration;

c. Dispute resolution and conflict over land;

d. Organizing the land management system;

e. Reforming the institutional / infrastructure improvements

\section{REFERENCES}

A.W.B. Simpson, 1986, A History of The LandLaw, Second Edition, Clarendon, PreesOxford,

Buang Salleh, 2010, Malaysian Torrens Sistem, Second Edition, Language and Literature Council, Kuala Lumpur,

Bowen, J. Theresa, 1995, Understanding Qualitative Research: A Review of Judith Meloys,

Chandra Syarifuddin, 2004 ,Certificate of Land Right, Mandar Maju, Bandung, , page 38

Chemberlain, Kerry, 1997, What is grounded Theory, Qualititative Recearh for the Human

Fajar Mukti, 2009, Dualisme of Normative and Empirical Legal Research,,

Harsono Boedi, 2001 Heading to the Improvement of the National Land Law in Linked Tap MPR-RI/IX/2001, University of Trisakti,

Hermit Herman, 2014, How to Obtain Property Rights, Land State, Land of Local Government and Practice of Land Registration in Indonesia, Mandar Maju, Bandung

Hutagalung Arie Sukanti, 2013 The Underlying Conception of Completion of the National Land Law, Inauguration Speech of Permanent Professor in Agrarian Law, Faculty of Law UI,

Hueser, Nicholas G,1999 Grounded Theory as Research Methdology,

Kurniati Nia, 2016 Agrarian Law Dispute Resolution through Arbitration In Theory And Practice, Refika Aditama 
Lexy J. Moeleong, 2014 Qualitative Research Methods Revised Edition, Remaja Rosdakarya, Bandung

Limbong Bernhard, 2015 Land Conflicts, Margaretha Pustaka, Jakarta

Maria Sumardjono, 2008 Mediation Land Conflict, Jakarta,

Megarry \& Wade, 1988The Law of Real Property, Fifth Edition, London;

Moore, Cristopher W. 1999, The Mediation Process Practical Strategis for Resolving Conflict, Jossey-Bass Publishers, San Francisco,

AP. Parlindungan, 1999 Land Registration, Mandar Maju, Bandung, page 256

Siti Megadianti Adam and, Takdir Rahmadi, 2003, Pilihan Penyelesaian Sengketa Di luar Pengadilan, Citra Aditya Bandung,

Sutendi Adrian, 2007, Transfer of Rights to Land and its Registration, Sinar Grafika, Jakarta.

Wong. S. Y.David, 1985, Tenure and Land Deadlings in the Malay State Singapore, Singapor University.

Yamin Muhammad dan Rahim Lubis, 2011, Land Registration Law, Mandar Maju, Bandung, 